\title{
The Resistance of European Beech (Fagus sylvatica) from the Eastern Natural Limit of Species to Climate Change
}

\author{
Marius BUDEANU ${ }^{1 *}$, Any Mary PETRITAN ${ }^{1}$, Flaviu POPESCU², \\ Diana VASILE ${ }^{1}$, Nicu Constantin TUDOSE ${ }^{1}$
}

\author{
${ }^{I}$ National Institutefor Research and Development in Forestry "Marin Dräcea", Brassov Research Station, 13 Cloşcastreet, 500040 Brasov, \\ Romania;budeanumarius@yahoo.com (*orrespondingauthor); apetritan@gmail.com; diana_vasile@ymail.com; cntudose@yahoo.com; \\ ${ }^{2}$ National Institutefor Research and Development in Forestry "Marin Dräcea", Simeria Research Station, 1 Biscariastreet, 335900 Simeria, Hunedoara county, \\ Romania;flaviupopescu@icashd.ro
}

\begin{abstract}
In this study, different approaches were used to investigate the vulnerability of beech forests, located at the eastern limit of their natural range, to climate change. To accomplish this, six $2500 \mathrm{~m}^{2}$ plots were sampled in four European beech forest genetic resources, located in Romania at different altitudinal levels, varying from 230 to $580 \mathrm{~m}$ in the Bacău hills and between 650 and $1300 \mathrm{~m}$ in the Curvature Carpathian (Braşov region). The analysis of trees phenotypic traits, their radial growth, and the regeneration, did not indicate a vulnerability of the sampled stands to the fluctuations of the environmental factors from the 1950-2014 period. The growth indices of all three populations of Bacău hills are negatively correlated with both June air temperature of current year and September of the previous year. The precipitation amount of September previous year positively influenced the growth indices. The radial growth of plots in Braşov region is slightly linked to the climate. The temperature during the growing season represents a limiting factor for stands that are located outside of the optimal altitudinal species distribution (600-1200 m, in Romania), especially at low altitudes. Our results indicated that a rise of the temperature accompanied by a possible reduction of the precipitations (as is predicted for the coming years) could increase the sensibility of beech forests at lower altitude.
\end{abstract}

Keywords: beech marginal populations, climatic parameters, quantitative traits, seedling characteristics, trees radial growth

\section{Introduction}

The European beech (Fagus sylvatica L.) has in Romania an altitudinal amplitude between 200-1600 m, which makes this species the best one to assess the influence of temperature and precipitation at different altitudes on future tree growth. The high sensitivity of the species to drought increases the vulnerability of beech to climate change especially at the eastern limit of the species (Kramer et al., 2010; Nahm et al., 2006).

Numerous studies have assessed the distribution of beech forests (Bolte et al., 2007; Czúcz et al., 2011; Fotelli et al., 2009; Kramer et al., 2010; Stojanović et al., 2013) at the lower limit of altitudinal distribution (i.e. xeric level) which is more difficult to determine than the upper limit, determined by temperature (Rasztovits, 2011).Special attention has been given to identifying some values that indicate beech resistance to drought in the context of climate change (Granier et al., 2007; Jump et al., 2007;
Silva et al., 2012). Therefore, numerous temperature and precipitation indices have been established in order to project a lower altitudinal limit of beech distribution for the future. In previous researches, negative correlations were found between the temperature during the vegetation season and radial growth. The correlation between precipitation (especially during the vegetation season) and growth were positive (Dittmar et al., 2003; Fotelli et al., 2009; Scharnweber et al., 2011).

Several studies showed coherent geographic patterns in the tree-ring growth response to climate, but these also depend upon local environmental gradients modulated by altitude or latitude (Di Filippo et al., 2007; Piovesan et al., 2005). For instance, analyses of Fagus sylvatica tree-ring width chronologies from south-western Europe have shown that May temperature and water availability in summer, together with the amount of winter precipitation, are the major drivers of radial growth (Lebourgeois et al., 2005; Piovesan et al., 2005).

In central Europe the predictions for the next 40 years indicate a temperature increase by approximately 2 degrees, while 
626

the precipitations remain constant. In the vegetation season the soil water availability will diminish and the beech vitality will be affected (Geßler et al., 2007). In Romania, in the period 19002005 an increase of mean temperature with $0.5^{\circ} \mathrm{C}$ was recorded (compared to $0.74^{\circ} \mathrm{C}$ the European average); this increase was doubled in the 1961-2007 period (Busuioc et al., 2010). For the 2021-2050 interval an increase of temperature with approximately $1.4{ }^{\circ} \mathrm{C}$ compared to the $1961-1990$ period is predicted for Romania. While in the 2071-2100 interval, the increase could be of up to $3.1^{\circ} \mathrm{C}$. In terms of precipitation, the 1900-2000 interval proved a decreasing trend of annual precipitation quantity (Busuioc et al., 2010).

To investigate the vulnerability degree of genetically improved beech forests to climatic factors, we sampled our plots in forest genetic resources of European beech. The forest genetic resources / seeds sources are populations phenotypic superior to other populations of their regions. The genetic value of these populations was increased by removing of trees with inferior quality.

In this study we attempt to:

- analyse the main phenotypic characteristics of trees and seedlings from four beech forest genetic resources situated at different levels of altitude and at the eastern limit of beech area;

- analyse the growth dynamic of investigated forests;

- investigate the influence of climatic factors on radial growth, with the aim to identify potential stress factors for beech.

\section{Materials and Methods}

Six plots were installed in four pure of European beech forest genetic resources in Romania (Table 1 ) and they were placed at different altitudinal levels $(230 \mathrm{~m}, 430 \mathrm{~m}, 580 \mathrm{~m}, 650 \mathrm{~m}, 1050 \mathrm{~m}$ and $1300 \mathrm{~m}$ a.s.l.), with at least $200 \mathrm{~m}$ altitude difference between the plots located in the same stand or adjacent stands. The plots are situated at the eastern European limit of natural distribution of beech (Fig. 1), three in the Curvature Carpathians (Braşov region) and the other three are placed along the Bacău hills area.

The European beech is a species adapted to moderate temperature values and in Romania the optimal altitudinal level is between $600 \mathrm{~m}$ and $1200 \mathrm{~m}$ (Şofletea and Curtu, 2007). The vegetation conditions are considered as unfavourable for beech both at higher elevation in the spruce-stand level (over 1300$1400 \mathrm{~m}$ ), due to lower temperatures, and at lower elevation (under $500 \mathrm{~m}$ ) due to its sensibility to drought and dryness
(Şofletea and Curtu, 2007). Therefore, we assume that environmental conditions in plots located at lower and higher elevation (230 m and $1300 \mathrm{~m}$, respectively) are suboptimalrestrictive for the beech.

In all plots (the design in Fig. 2) the main phenotypic traits of the trees were analysed: diameter at breast height (dbh), total height, pruning height, forking height, stem shape, and stem straightness.

The dbhs were measured using the forest calliper $(1 \mathrm{~mm}$ precision), while the total height, pruning height and the forking height were measured using a Vertex III instrument (Haglöf, Sweden) at a precision of $0.1 \mathrm{~m}$. By using predefined indices, a visual assessment on qualitative traits of the trunk were made: the general form of the stem ( $1=$ unitary, $2=$ forked, $3=$ many forked), the straightness of the trunk ( $1=$ straight trunk, $2=$ curvature in the upper third of the pruning height; $3=$ curvature in the middle third of the pruning height; $4=$ curvature in the lower third of the pruning height; $5=$ sinuous stem). The volume of trees was calculated based on dbh, total height and species type, by using the regression equation of volume procedure (Giurgiu et al., 2004).

The tree characteristics and the radial growth differences between plots were tested with the non-parametric MannWhitney UTest, $\mathrm{p}<0.05$, since the data did not comply with the requirements of parametric test methods.

Seedlings analysis was made starting from the idea advanced by Silva et al. (2012) that natural regeneration represents a vital condition for beech survival faced with climatic changes. The seedlings (with a height $<200 \mathrm{~cm}$ ) from each plot were recorded and described in five circular areas of $2 \mathrm{~m}^{2}$, one located in the middle of the plot, and other four on the cardinal directions (Fig. $2)$. The following traits were determined: seedling height $(\mathrm{cm})$, seedlings stem quality $(1=$ monopodial growth; $2=$ sloping trunk; 3 = curved trunk; 4 = forking), seedlings stem viability (1 $=$ unharmed lateral stems; 2 = below $10 \%$ stems harmed; $3=10$ $50 \%$ stems harmed; $4=$ over $50 \%$ stems harmed). In addition to this detailed assessment, an overall description of beech seedling (visual assessment) was completed both on the surface of the plots and on the entire forest units in which the plots are located.

The cores from a total of 30 trees were collected from each plot, respecting the diameter class distribution of trees, using the Pressler drill. The cores were extracted from a height of $1.30 \mathrm{~m}$ by sequentially changing the cardinal direction (North, East, South, and West) of extraction (Badea, 2008). Measurements of the annual growth were recorded using the CooRecorder software

Table 1. The location of the tested populations

\begin{tabular}{|c|c|c|c|c|c|}
\hline Populations & Administrative location & $\begin{array}{l}\text { Latitude } \mathrm{N} \\
\text { Longitude } \mathrm{E} \\
\text { Altitude }(\mathrm{m})\end{array}$ & $\begin{array}{l}\text { Surface } \\
\text { (ha) }\end{array}$ & $\begin{array}{l}\text { Exposition } \\
\text { Slope }\end{array}$ & Number of plots / altitude a.s.l. \\
\hline Braşov 1 & $\begin{array}{l}\text { F.D. Pădurile Şincii } \\
\text { UB Şinca Veche u.a. } 103\end{array}$ & $\begin{array}{c}45^{\circ} 42^{\prime} \\
25^{\circ} 11^{\prime} \\
590-750\end{array}$ & 31.4 & $\begin{array}{l}\mathrm{NE} \\
15^{\mathrm{G}}\end{array}$ & $\begin{array}{c}1 \\
\text { at } 650 \mathrm{~m}\end{array}$ \\
\hline Braşov 2 & $\begin{array}{l}\text { F.D. Piatra Craiului } \\
\text { UB Zărneşti u.a. 179B }\end{array}$ & $\begin{array}{c}45^{\circ} 39^{\prime} \\
25^{\circ} 11^{\prime} \\
1000-1380\end{array}$ & 25.3 & $\begin{array}{l}S E \\
24^{\mathrm{G}}\end{array}$ & $\begin{array}{c}2 \\
\text { at } 1050 \text { and } 1300 \mathrm{~m}\end{array}$ \\
\hline Bacău 1 & $\begin{array}{c}\text { F.D. Fântânele } \\
\text { UP II Fântânele u.a. } 66,82 \mathrm{D}\end{array}$ & $\begin{array}{c}46^{\circ} 37^{\prime} \\
26^{\circ} 48^{\prime} \\
230-430\end{array}$ & 48.8 & $\begin{array}{l}\mathrm{NE} \\
12^{\mathrm{G}}\end{array}$ & $\begin{array}{c}\mathbf{2} \\
\text { at } 230 \text { and } 430 \mathrm{~m}\end{array}$ \\
\hline Bacău 2 & $\begin{array}{c}\text { F.D. Livezi } \\
\text { UP III Coman u.a. 19A }\end{array}$ & $\begin{array}{c}46^{\circ} 28^{\prime} \\
26^{\circ} 49^{\prime} \\
400-580\end{array}$ & 22.9 & $\begin{array}{c}\mathrm{N} \\
25^{\mathrm{G}}\end{array}$ & $\begin{array}{c}\mathbf{1} \\
\text { at } 580 \mathrm{~m}\end{array}$ \\
\hline
\end{tabular}

F.D. $=$ Forest district, $\mathrm{UB}=\mathrm{Base}$ unit, $\mathrm{UP}=$ Production unit, u.a. $=$ parcel. 

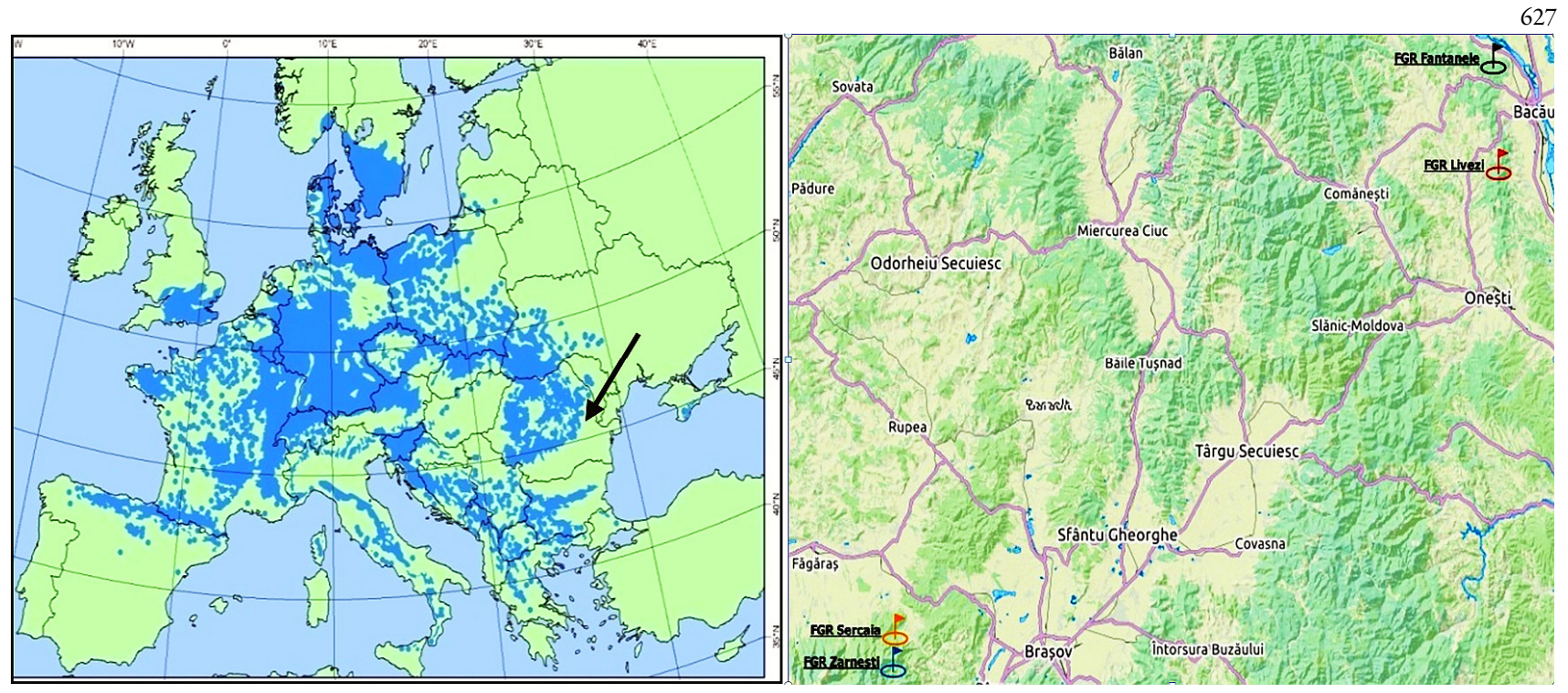

Fig. 1. Geographic distribution of Fagus sylvatica in Europe (www.enforgen.org), with outline (arrow) of the study area (left) and the location of plots (right, http://www.openstreetmap.org)

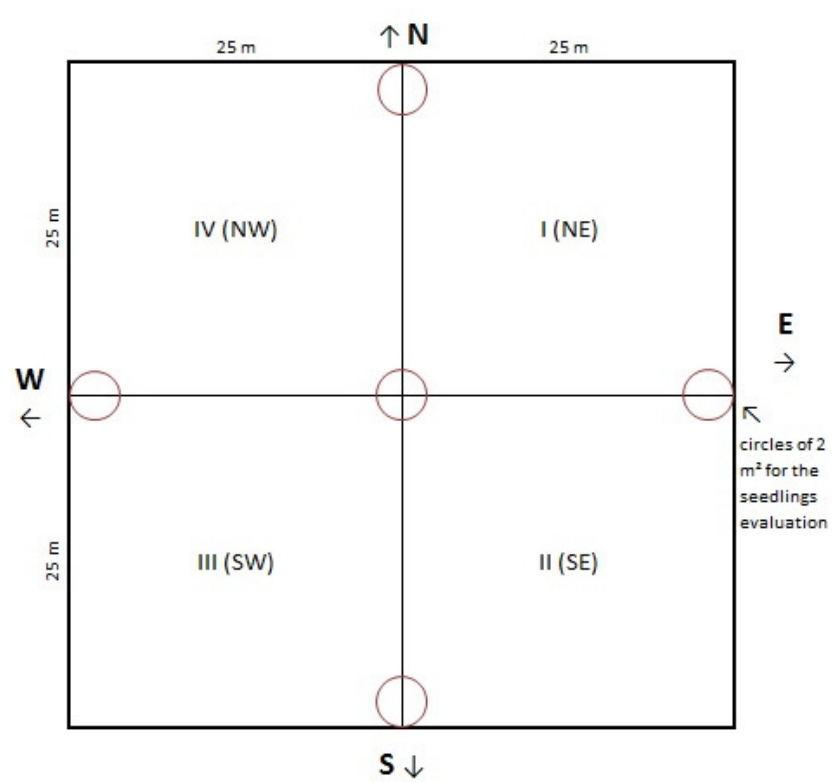

Fig. 2. The plot design

(Cybis Elektronik \& Data AB, 2015; www.cybis.se). The primary analysis of data and saving of the results in a format that allows other subsequent analysis were performed using the CDendro program (www.cybis.se). The chronology of the annual rings was checked visually and statistically using the COFECHA program (Holmes, 1983). In order to eliminate the influence of age on achieving growth as well as obtaining the standardized growth indices, the ARSTAN program (Cook and Kruse, 2006) was used.

For the standardized indices of radial growth, only cores from dominant trees were used, which have been well crossdated (correlations higher than 0.5). In order to highlight the climate information, all series of individual growth were standardized therefore achieving a transformation of a series of nonstationary growth in a number of stationary indices with an average of 1 and a relatively constant variance (Popa, 2004). To eliminate the influence of age we applied a cubic spline function with a frequency equal to $67 \%$ of the length of the series (Cook and Kairiukstis, 1990; Leca, 2014). The transformation in the Excel format was performed using TRiCYCLE software (Brewer et al., 2011).

The climatic data from 1950-2014 was collected from the following websites: CRU (http://www.cru.uea.ac.uk; Hulme et al., 1998; Ceda catalogue, 2014; Osborn and Jones, 2014; CRU Dataset, 2015), Worldclim (http://www.worldclim.org) and ECA\&D (bttp://www.ecad.eu, Klein Tank et al., 2002; ECA\&D, 2015). This data is centralized from weather stations Făgăraş and Bacău, located closest to the plots.

For a better expression of climate favourability range, a number of climatic indices were calculated and the values were compared with the thresholds considered as limiting for the beech.

- De Martonne aridity index:

$\mathbf{I}_{\mathrm{A}}=\frac{\mathrm{P}}{\mathrm{T}+\mathbf{1 0}}$, where $\mathrm{P}=$ the amount of the annual precipitation, $\mathrm{T}=$ average annual temperature. $\mathrm{I}_{\mathrm{A}}<30=$ silvosteppe, $30<\mathrm{I}_{\mathrm{A}}<$ 45 = climate favourable for the forest, with an optimal for beech in the range 35 - 40 (Satmari, 2010).

\section{- EllenbergQuotient:}

$\mathbf{E Q}=\frac{\mathbf{T}_{\mathrm{W}}}{\mathrm{P}} \times \mathbf{1 0 0 0}$, where $\mathrm{T}_{\mathrm{W}}$ represents the temperature of the warmest month of the year, $\mathrm{P}=$ annual precipitations (Stojanović et al., 2013). Ellenberg (1988) has set a threshold of beech favourability for EQ values lower than 30 , and at EQ values that are higher than 40 , the beech disappearance occurs.

- Forestry Aridity Index:

FAI $=\mathbf{1 0 0} \times \frac{\mathrm{T}_{\mathrm{VII}}-\mathrm{VIII}}{\mathrm{P}_{\mathrm{V}-\mathrm{VII}}+\mathrm{P}_{\mathrm{VII}}-\mathrm{VIII}}$, where $\mathrm{T}_{\mathrm{VII}-\mathrm{VIII}}$ is the average temperature of the months July and August, $P_{V-V I I}$ represents the amount of precipitations during May-July and PVII-VII is the amount of precipitations during July-August (Führer et al., 2011). Führer and collaborators consider that the climatic 
628

conditions are favourable for beech at FAI values that are less than 4.75 .

\section{- Fagus Favourability Index:}

$\mathbf{F I}=\frac{\mathbf{P}}{\mathbf{A l t}}$, also known as the Continentality Gams index, is the result by reporting the annual precipitation to the altitude of the test site. IFF values between 1 and 2 are favourable for the beech (Satmari, 2010).

$$
\text { -Mayr Tetratherm: }=\frac{\mathbf{t}_{\mathrm{V}}+\mathbf{t}_{\mathrm{VI}}+\mathrm{t}_{\mathrm{VII}}+\mathrm{t}_{\mathrm{VIII}}}{\mathbf{4}} \text {, }
$$

where $t_{V}-t_{V I I I}$ represent the temperatures for the maximum aridity period of the year (May-August). Tetratherm values indicate a climate restrictiveness of an area for some plant formations. Values between 13 and 18 degrees are optimal for the beech (Satmari, 2010).

In order to calculate the correlations with the climatic factors the dendrochronological residual series were used. The correlations coefficients between standardized radial growth indices and climatic factors (air temperature and precipitation) were calculated using the R software.

\section{Results and Discussion}

\section{The climate of the testing sites}

Both in the Bacău Hills and the Brașov Depression, where the plots are located, the climate is D.f.b.x. after Köppen classification, respectively a boreal climate with wet winters and with sufficient precipitations all around the year (Df), at least 4 months a year the mean temperature exceeds $10{ }^{\circ} \mathrm{C}(\mathrm{b})$, the maximum of precipitations quantity is in May-June, and the minimum of precipitations quantity is in late winter $(\mathrm{x})$.

In the plot from Sercaia the vegetation conditions are optimal for beech (Table 2), where climatic parameters are optimal, except for the Ellenberg index exceeding the optimal value with a unit. Similarly, in the plots Zărneşti 1 (1050 m a.s.l.) and Livezi (580 $\mathrm{m}$ a.s.l.) were recorded favourable conditions for beech, while in the plots from higher and lower elevation, vegetation conditions are very limitative (such as Zărnești 2 1300 m a.s.l.).

\section{Characterization of the studied populations}

Although according to the climatic indices analysis, the beech population from Fântânele 1 (F1), located at lower elevation $(230 \mathrm{~m})$, should be an unfavourable area for the beech, the biometric characteristics of this population are remarkable. This population has the highest average age (138 years, Table 4 ) and the lowest density of trees per hectare (132, Table 3). In this plot there were recorded trees with $106 \mathrm{~cm}$ dbh and with heights up to $43 \mathrm{~m}$ (Table 3).

But in this plot more curved trunks were found compared with the other plots (Table 3). The other population from Fântânele (F2) has also a high bioaccumulation capacity, having beech trees with up to $45 \mathrm{~m}$ height and up to $73 \mathrm{~cm} \mathrm{dbh}$. The stem trunk quality is better than those of F1 plot. The volume per hectare of F2 plot $\left(883.5 \mathrm{~m}^{3}\right)$ is $31 \%$ higher than the volume recorded of $\mathrm{F} 1$ population. Both populations ( $\mathrm{F} 1$ and $\mathrm{F} 2$ ) have a similar average radial growth, slightly lower for $\mathrm{F} 2$ even if this plot is of lower age (Table 4). The superiority of $\mathrm{F} 1$ plot regarding the radial growth is more accentuated in the past 10 years (the growth average - $1.61 \mathrm{~mm}$ for F1 and $1.27 \mathrm{~mm}$ for F2, Fig. 3). The third beech plot researched from the Bacău area is the youngest one, with an average age of 85 years, having also the highest value for the average radial growth (Table 4). The negative correlation between radial growth and trees age has been already reported (i.e. Rozas et al., 2015). In this plot the maximum height of the trees is approximately $10 \mathrm{~m}$ lower than in the other plot from the same area (Table 3).

The maximum tree height from the Braşov beech populations is lower than the maximum height of Fântânele (F1 and F2) and similar to the tree height from the much younger population from Livezi, Bacău area (Table 3). The three plots from Braşov are the same age, of approximately 100 years, which allows a comparative analysis of growth, without the risk of being influenced by the reducing of annual ring width with age. Thus, a significant reduction of the average growth can be observed with the increasing of the altitude (Fig. 3, Table 4). The Z2 plot being at the highest altitude $(1300 \mathrm{~m})$ has an average growth $(1.46$ $\mathrm{mm}$ ) approximately $34 \%$ lower than the $S$ plot (S,ercaia), which is located at the optimal altitude $(650 \mathrm{~m})$ and enjoys optimal vegetation conditions for beech (Table 4). The same observation is valid for the average growth of the past 10 years, this being $51 \%$ lower for the Z2 plot which is located at $1300 \mathrm{~m}$ altitude (Fig. 3). In the plot situated at the highest altitude were recorded the lowest value of average radial growth and also the lowest averages from the past 10 years of all the 6 plots (Fig. 4). For the plot located at the highest altitude, the reduction of growth in the past 50 years represents a constant trend, while in the other areas there are fluctuations in time (Fig. 4).

The mean radial growths (higher with 32\% than those described by Leca (2014) for other beech stands from Brașov area with the same age) do not reveal vulnerabilities to fluctuations in environmental factors for the studied beech populations. Vulnerability analysis of forest species from the Southern Carpathians (the Retezat and Bucegi - Piatra Craiului Massifs) reflected a superior resistance of beech to environmental disturbances (Badea et al., 2011), in comparison with other analyzed species.

Table 2. Bioclimatic indices from the analysed plots

\begin{tabular}{|c|c|c|c|c|c|c|c|c|c|}
\hline Plot & $\begin{array}{c}\text { MAT } \\
\left({ }^{\circ} \mathrm{C}\right)\end{array}$ & $\begin{array}{l}\text { SAP } \\
(\mathrm{mm})\end{array}$ & $\begin{array}{c}\text { ATVS } \\
\left({ }^{\circ} \mathrm{C}\right)\end{array}$ & $\begin{array}{l}\text { SPVS } \\
(\mathrm{mm})\end{array}$ & $\mathrm{I}_{\mathrm{A}}$ & FFI & EQ & FAI & $\begin{array}{l}\text { MT } \\
\left({ }^{\circ} \mathrm{C}\right) \\
\end{array}$ \\
\hline Fântânele $1230 \mathrm{~m}$ a.s.l. & 9.3 & 572 & 18.3 & 348 & 30 & $\underline{2.5}$ & 38 & $\underline{5.87}$ & 19.0 \\
\hline Fântânele $2430 \mathrm{~m}$ a.s.l. & 9.3 & 572 & 18.3 & 348 & 30 & 1.3 & 38 & 5.87 & 19.0 \\
\hline Livezi $580 \mathrm{~m}$ a.s.l. & 8.6 & 595 & 17.4 & 352 & 32 & 1.0 & 34 & 5.25 & 18.2 \\
\hline Şercaia $650 \mathrm{~m}$ a.s.l. & 8.3 & 649 & 16.7 & 409 & 35 & 1.0 & 31 & 4.5 & 17.3 \\
\hline Zărneşti 11050 m a.s.l. & 4.6 & 773 & 9.2 & 487 & 53 & 0.7 & 14 & 2.1 & 9.5 \\
\hline Zărneşti 21300 m a.s.l. & $\underline{3.1}$ & 823 & $\underline{6.1}$ & 518 & $\underline{63}$ & $\underline{0.6}$ & 9 & 1.3 & $\underline{6.4}$ \\
\hline
\end{tabular}

$\underline{M A T}=$ mean annual temperature, $\mathrm{SAP}=$ sum of annual precipitation, ATVS/SPVS= average temperature/sum of precipitation of the growing season $(\mathrm{May}$ September), $\mathrm{I}_{\mathrm{A}}=\mathrm{De}$ Martonne aridity index, $\mathrm{FFI}=$ Fagus favourability index, $\mathrm{EQ}=$ Ellenberg index, $\mathrm{FAI}=$ forestry aridity index, $\mathrm{MT}=\mathrm{Mayr} \mathrm{May}-\mathrm{August}$ average temperature. bold= optimal value, normal= acceptable value, underlined= limitative value, according to Şofletea and Curtu (2007). The climatic data were collected from the Făgăraş and Bacău weather stations. 
Table 3. Trees characteristics

\begin{tabular}{|c|c|c|c|c|c|c|c|c|}
\hline $\begin{array}{c}\text { Plot } \\
\text { No. of trees / } \\
2500 \mathrm{~m}^{2} \text { Altitude } \\
\text { a.s.l. } \\
\end{array}$ & Variable & $\begin{array}{l}\text { Diameter at } \\
\text { breast height } \\
\quad(\mathrm{cm})\end{array}$ & $\begin{array}{l}\text { Total height } \\
\text { (m) }\end{array}$ & $\begin{array}{l}\text { Average trees } \\
\text { volume } \\
\left(\mathrm{m}^{3}\right)\end{array}$ & $\begin{array}{l}\text { Pruning height } \\
\text { (m) }\end{array}$ & $\begin{array}{l}\text { Forking height } \\
\text { (m) }\end{array}$ & $\begin{array}{l}\text { Stem shape } \\
\text { (indices) }\end{array}$ & $\begin{array}{l}\text { Stem straightness } \\
\text { (indices) }\end{array}$ \\
\hline Fântânele 1 & Mean & $53.4 \mathrm{a}$ & $35.1 \mathrm{a}$ & $5.11 \mathrm{a}$ & 16 a & $11 \mathrm{ac}$ & $1.5 \mathrm{ab}$ & $2.5 \mathrm{a}$ \\
\hline 33 trees & Std. dev. & 18.7 & 5.6 & 4.4 & 5.2 & 4.5 & 0.7 & 1.7 \\
\hline $230 \mathrm{~m}$ & Amplitude & $106-24$ & $43-21$ & $22-0.5$ & $26-6$ & $17-5$ & $3-1$ & $5-1$ \\
\hline Fântânele 2 & Mean & $43.6 \mathrm{~b}$ & $39.4 \mathrm{~b}$ & $3.30 \mathrm{~b}$ & $25 \mathrm{~b}$ & $16 \mathrm{~b}$ & $1.4 \mathrm{~b}$ & $1.9 \mathrm{ab}$ \\
\hline 67 trees & Std. dev. & 10.6 & 2.9 & 1.9 & 4.7 & 3.9 & 0.6 & 1.2 \\
\hline $430 \mathrm{~m}$ & Amplitude & $73-24$ & $45-30$ & $9.8-0.8$ & $36-15$ & $21-7$ & $3-1$ & $5-1$ \\
\hline Livezi & Mean & $39.9 \mathrm{c}$ & $27.8 \mathrm{c}$ & $1.94 \mathrm{c}$ & $16 \mathrm{a}$ & $9 a$ & $1.6 \mathrm{ab}$ & $2.1 \mathrm{a}$ \\
\hline 74 trees & Std. dev. & 10.7 & 2.3 & 1.2 & 2.6 & 5.1 & 0.6 & 1.2 \\
\hline $580 \mathrm{~m}$ & Amplitude & $67-19$ & $33-23$ & $5.6-0.3$ & $22-9$ & $17-2$ & $3-1$ & $5-1$ \\
\hline Şercaia & Mean & $35.1 \mathrm{~d}$ & $27.3 c$ & $1.55 \mathrm{c}$ & $13 \mathrm{c}$ & $12 \mathrm{c}$ & $1.6 \mathrm{a}$ & $1.5 \mathrm{~b}$ \\
\hline 82 trees & Std. dev. & 10.4 & 4.0 & 1.0 & 4.9 & 3.9 & 0.5 & 1.1 \\
\hline $650 \mathrm{~m}$ & Amplitude & 63-12 & $34-13$ & $4.6-0.1$ & $21-3$ & $18-5$ & $3-1$ & $5-1$ \\
\hline Zărneşti 1 & Mean & $37.9 \mathrm{~cd}$ & $27.0 \mathrm{c}$ & $1.89 \mathrm{c}$ & $13 c$ & $10 \mathrm{ac}$ & $1.5 \mathrm{ab}$ & $1.5 \mathrm{~b}$ \\
\hline 75 trees & Std. dev. & 13.9 & 4.2 & 1.6 & 5.1 & 4.9 & 0.7 & 1.1 \\
\hline $1050 \mathrm{~m}$ & Amplitude & $71-14$ & $34-17$ & $7.3-0.1$ & $24-2$ & $20-4$ & $3-1$ & $5-1$ \\
\hline Zărneşti 2 & Mean & $27.5 \mathrm{e}$ & $21.1 \mathrm{~d}$ & $0.80 \mathrm{~d}$ & $10 \mathrm{~d}$ & $8 \mathrm{a}$ & $1.7 \mathrm{a}$ & $2.0 \mathrm{ab}$ \\
\hline 134 trees & Std. dev. & 11.2 & 3.5 & 0.8 & 4.5 & 4.4 & 0.8 & 1.7 \\
\hline $1300 \mathrm{~m}$ & Amplitude & $61-12$ & $30-12$ & $3.9-0.1$ & $19-2$ & $17-2$ & $3-1$ & $5-1$ \\
\hline
\end{tabular}

Each plot has a square-shape and an area of $2500 \mathrm{~m}^{2}(50$ x $50 \mathrm{~m})$. Std. dev.= standard deviation, Amplitude= Maximal to minimal values. The different letters show the significant differences between plots (Man-Whitney U-Test, $\mathrm{p}<0.05$ )

Table 4. Cores characteristics

\begin{tabular}{|c|c|c|c|c|c|c|c|c|c|}
\hline \multirow{2}{*}{ Plot } & \multirow{2}{*}{$\begin{array}{c}\text { Number of } \\
\text { cores }\end{array}$} & \multicolumn{3}{|c|}{ Age (years) } & \multicolumn{3}{|c|}{ Radial growth $(\mathrm{mm})$} & \multirow{2}{*}{ R bar } & \multirow{2}{*}{ EPS } \\
\hline & & Mean & Minimum & Maximum & Mean & Minimum & Maximum & & \\
\hline F1 & 21 & 138 & 107 & 164 & 1.953 & 1.256 & 3.080 & 0.401 & 0.922 \\
\hline F2 & 21 & 106 & 97 & 126 & 1.887 & 1.290 & 2.505 & 0.368 & 0.905 \\
\hline $\mathrm{L}$ & 20 & 85 & 72 & 96 & 2.374 & 1.194 & 4.049 & 0.374 & 0.907 \\
\hline$S$ & 19 & 101 & 85 & 120 & 1.959 & 1.212 & 2.737 & 0.445 & 0.924 \\
\hline Z1 & 20 & 106 & 89 & 124 & 1.760 & 1.174 & 2.639 & 0.332 & 0.881 \\
\hline $\mathrm{Z} 2$ & 17 & 100 & 85 & 111 & 1.463 & 1.083 & 1.927 & 0.328 & 0.850 \\
\hline
\end{tabular}

F1 = Fântânele 1, F2 = Fântânele 2, L= Livezi, S= Șercaia, Z1 = Zărnești 1, Z2 = Zărnești 2.

30 cores/plot were collected but only those which have been crossdated were used. Rbar is the mean correlation coefficient among tree-ring series. EPS is the expressed populations signal.

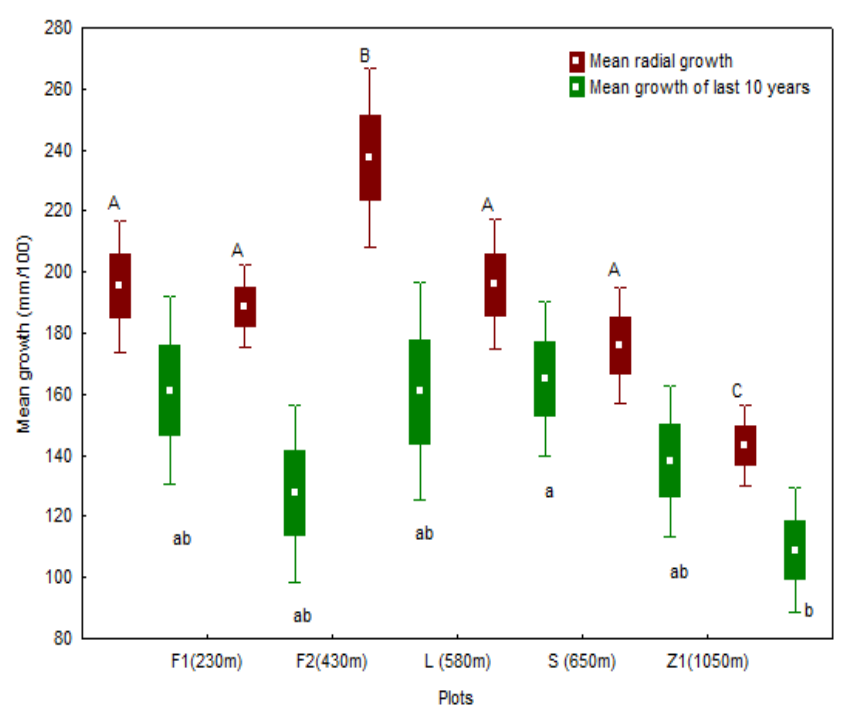

Fig. 3. Mean radial growth of entire tree life and mean radial growth of the last 10 years (2005-2014). Box values represent the standard error and whiskers values the confidence interval. F1 -Fântânele 1, F2 - Fântânele 2, L - Livezi, S - Şercaia, Z1 Zărneşti 1, Z2 - Zărnești 2). The different letters show the significant differences between plots (Man-Whitney U-Test, $\mathrm{p}<0.05$
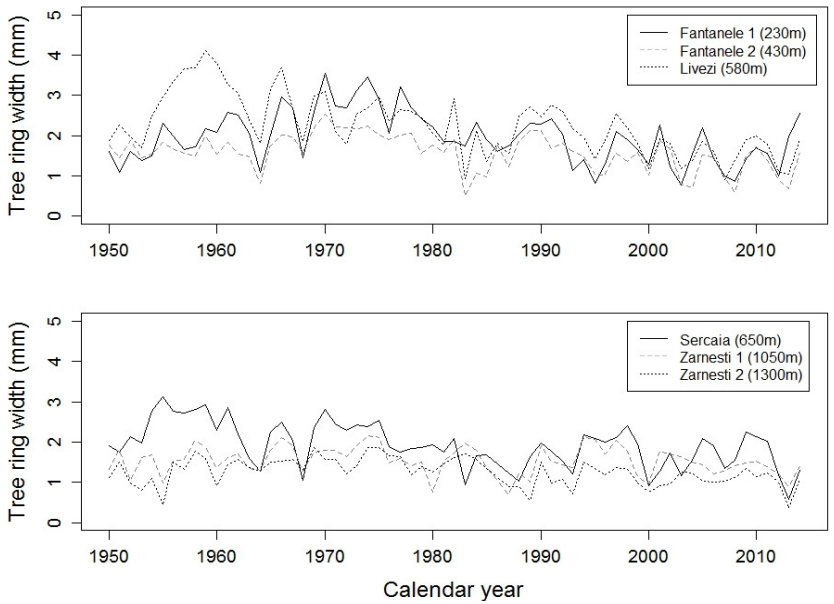

Fig. 4. The growth curves (mean width) of the studied plots during 1950-2014

\section{Seedlings analysis}

In the area situated at the lowest altitude (Fântânele 1),74\% of the identified seedling has monopodial growth or slightly inclined trunk and lateral shoots have slight damages not affecting their growth (Table 5).

In the plot from Fântânele 2, assessed seedlings are approximately $2-3$ years old and they are less numerous than in the other plots. In this plot as well as in the whole forest stand the 
630

Table 5. Description of seedlings from the 5/plot circular surfaces installed

\begin{tabular}{lcccccccccc}
\hline Plot & $\begin{array}{c}\text { Number of } \\
\text { seedlings }\end{array}$ & $\begin{array}{c}\text { Seedling height/ } \\
\text { amplitude (cm) }\end{array}$ & \multicolumn{3}{c}{$\begin{array}{c}\text { Seedling stem quality } \\
\text { (numbers/classes) }\end{array}$} & \multicolumn{1}{c}{$\begin{array}{c}\text { Seedling stem viability } \\
\text { (numbers/classes) }\end{array}$} \\
\hline Fântânele 1 & 31 & $21(10-80)$ & 4 & 19 & 2 & 6 & 2 & 28 & 1 \\
Fântânele 2 & 13 & 10 & 0 & 8 & 5 & 0 & 0 & 3 & 4 \\
Livezi & 26 & $33(15-100)$ & 1 & 11 & 3 & 11 & 0 & 18 & 8 & 0 \\
Şercaia & 45 & $78(20-180)$ & 22 & 12 & 4 & 7 & 15 & 26 & 2 & 2 \\
Zărneşti 1 & 23 & $44(10-200)$ & 8 & 6 & 2 & 7 & 11 & 12 & 0 & 0 \\
Zărnești 2 & 0 & - & - & - & - & - & - & - & - & -
\end{tabular}

Seedling stem quality: $1=$ monopodial growth; $2=$ sloping trunk; $3=$ curved trunk; $4=$ forking. Seedling stem viability: $1=$ unharmed lateral stems; $2=$ below $10 \%$ stems harmed; $3=10 \%-50 \%$ stems harmed; $4=$ over $50 \%$ stems harmed.

crown density of the stand is 0.8-0.9 and the seedling is absent. In the plot from Livezi, where the crown density of the stand is $\leq$ 0.7 the seedling occurs on $30 \%$ of the area. In the plot from Șercaia, seedling has monopodial growth or slightly inclined trunk (Table 5). In the plot from Zărnești 1, which is located at $1050 \mathrm{~m}$ altitude, $61 \%$ of identified seedlings have monopodial growth or slightly inclined trunk, while $30 \%$ of these have bifurcation (Table 5). In the plot seedlings are recorded especially on the slope facing SE and SW, where the crown density of the stand is much lower $(0.55$, compared to 0.8 from the north aspect of the surface). In the plot from Zărnesti 2, which is located at the highest altitude, no seedlings have been identified, the main reason being the high canopy closure of the stand (0.9). The seedlings are missing over the entire surface of stand.

Therefore, beech seedlings were identified in most of the plots and its density was influenced by the canopy closure of the stand, which limits the amount of light on the ground level. Currently, the presence and the quality of seedling (Silva et al., 2012), do not indicate a vulnerability of the analyzed beech forests to major environmental fluctuations, if we agree with the hypothesis proposed by Silva.

\section{The influence of climatic factors on the annual radial growths}

In Bacau, the records showed a general increasing trend both for the air temperature and rainfall, throughout the period under analysis. In Braşov, starting from 1985 onwards, the records for the air temperature exhibited an upward trend. However, the records for rainfall, showed a slight downward trend over the entire period under analysis (Fig. 5).

The standard indices of growth (see Fig. 6) show that the years with the lowest growth in all plots under analysis were

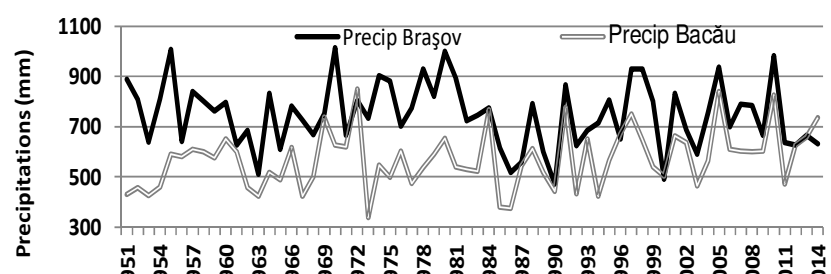

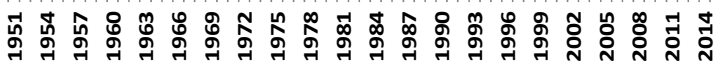

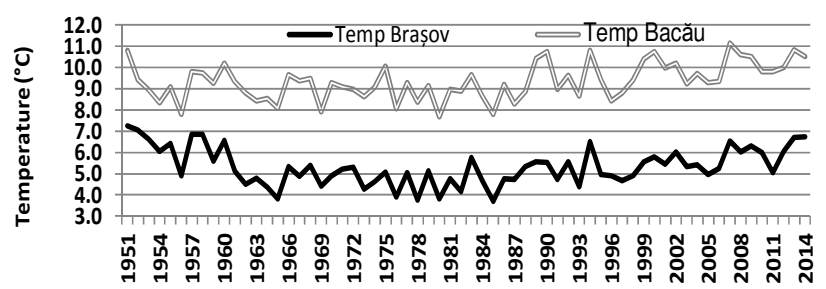

Fig. 5. The dynamic of the annual temperature and precipitations from the analyzed plots
1964, 1968, 1983, 1985, 1987, 2000, 2003, 2007, 2012 and 2013. With the exception of 1968, all the other years mentioned above are known in Romania as 'dry' years (Sandu, 2013). At the opposite end, the years with the highest rates of growth in all areas were: 1959, 1969, 1974, 1990, 1994, 1997, 2001,2005 and 2014. Out of this second set of years, 1969, 1974, 1990, 1997, 2005 and 2014 are known in Romania as 'rainy' years (Sandu, 2013).

Table 6 and Fig. 7 show the correlations between residual radial growth indices and climatic factors. For all three plots studied in Bacău, radial growth indices showed a negative correlation with temperature of the June, current year. In addition, the analysis showed that the intensity of this correlation is inversely proportional to the altitude (Fig. 7). The radial growths were negatively influenced by the temperatures registered in the month of September the previous year. However, the amount of rainfall recorded for the same month had a significantly positive influence on the tree growth. For the populations in Bacau - especially from the one located at the lower altitudinal limit - the negative correlation with summer temperature and the positive correlations with summer precipitations point to the fact that the summer (i.e. June) water availability is the main driving factor of growth for beech trees, in accordance with the results from other studies (Bouriaud et al., 2004; Michelot et al., 2012; Oladi et al, 2011). In addition, the results suggest that the water availability during September (the previous year) was an important factor for the growth formation, probably due the contribution of the soil water reserve.
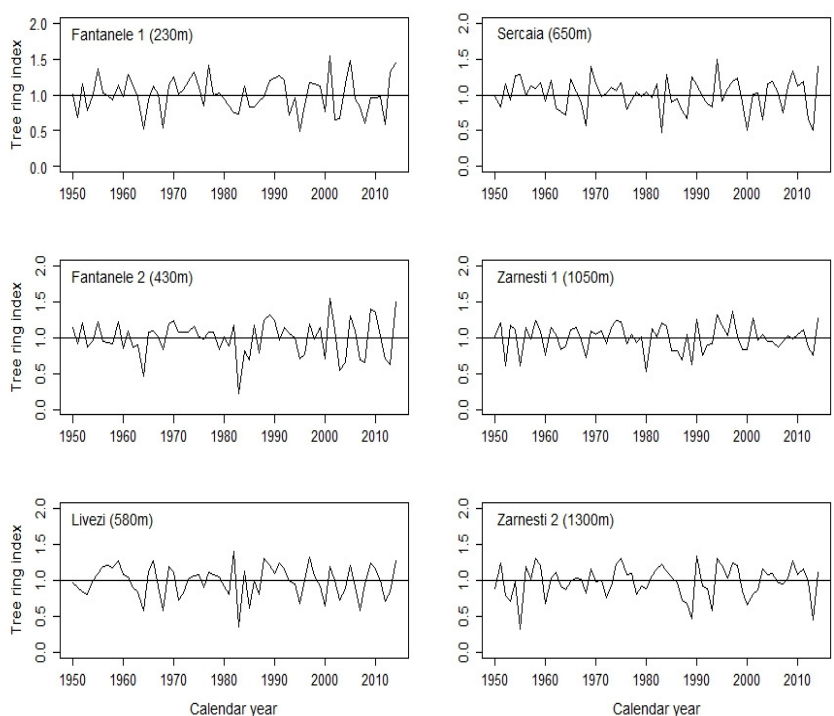

Fig. 6. Residual chronologies of the studied plots at Bacau (left) and Brasov (right) 
Table 6. Indices of correlation between radial growth and climatic factors

\begin{tabular}{|c|c|c|c|c|c|c|}
\hline \multirow{3}{*}{ Climatic Factors } & \multicolumn{3}{|c|}{ Bacău } & \multicolumn{3}{|c|}{ Braşov } \\
\hline & Fântânele 1 & Fântânele 2 & Livezi & Şercaia & Zărneşti 1 & Zărneşti 2 \\
\hline & $230 \mathrm{~m}$ & $430 \mathrm{~m}$ & $580 \mathrm{~m}$ & $650 \mathrm{~m}$ & $1050 \mathrm{~m}$ & $1300 \mathrm{~m}$ \\
\hline Average annual temperature & 0.04 & 0.05 & -0.05 & 0.02 & 0.05 & -0.10 \\
\hline Average temperature of the vegetation season & -0.25 & -0.09 & -0.17 & -0.06 & 0.06 & -0.08 \\
\hline Sum of the annual precipitations & 0.26 & 0.23 & 0.34 & 0.26 & 0.06 & 0.05 \\
\hline Sum of precipitations of the vegetation season & 0.26 & 0.19 & 0.23 & 0.27 & 0.09 & 0.05 \\
\hline Ellenberg index & -0.23 & -0.15 & -0.31 & -0.28 & -0.06 & -0.13 \\
\hline FAI index & -0.19 & -0.12 & -0.23 & -0.37 & -0.14 & -0.22 \\
\hline De Martonne aridity index & 0.24 & 0.21 & 0.34 & 0.25 & 0.03 & 0.08 \\
\hline Mayr Tetraterma & -0.28 & -0.13 & -0.20 & -0.14 & 0.05 & -0.09 \\
\hline Fagus favourability index & 0.26 & 0.23 & 0.34 & 0.26 & 0.06 & 0.05 \\
\hline
\end{tabular}

The significant correlations $(\mathrm{p}<0.05)$ are bolded

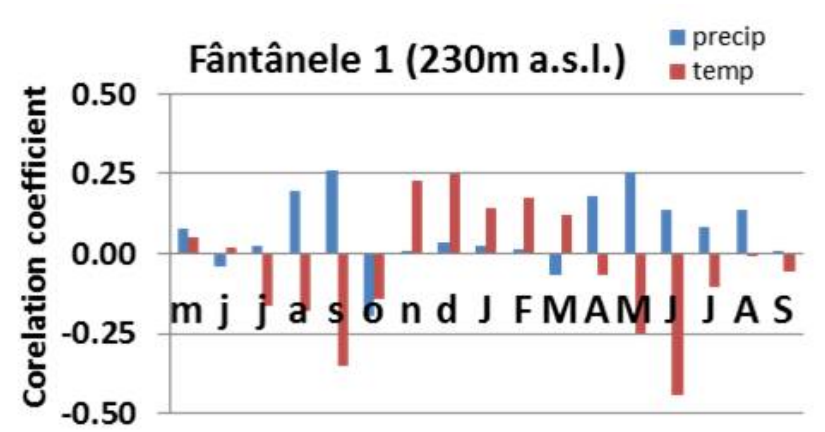

Fântânele 2 (430m a.s.l.)
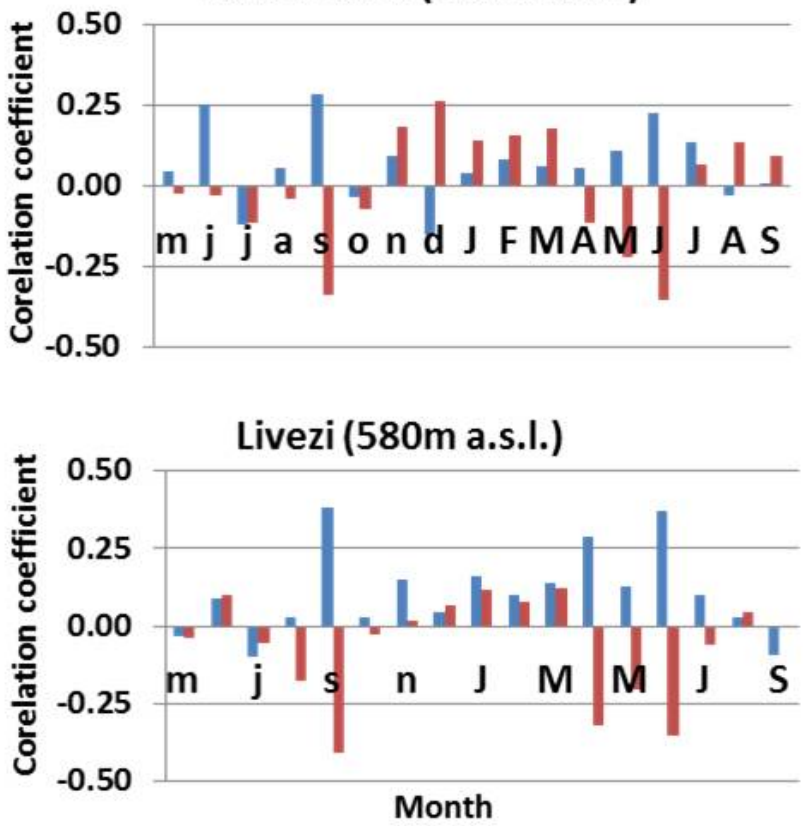
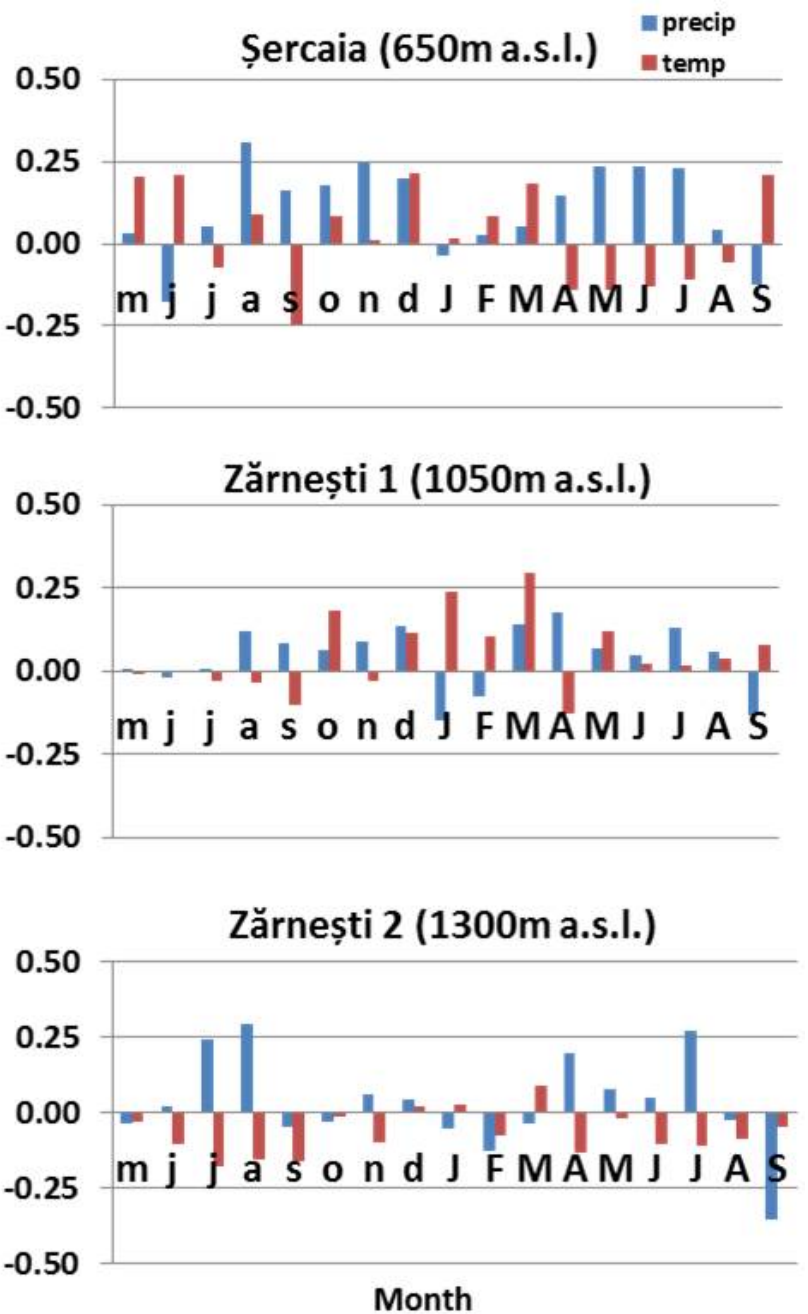

Fig. 7. The influence of monthly temperature and precipitation values of the previous year (small letters) and the current year (capital letters) on the radial growth of trees. Values higher than $0.25 /-0.25$ are significant $(\mathrm{p}<0.05)$

Concerning the beech populations in Brasov, the results showed very few significant correlations with climatic factors. The growth of the beech from plot located in Șercaia (although positioned in an ecologically optimal environment) seemed to have been negatively influenced by the August rainfall and by the temperature recorded in September last year. However, the rainfall recorded this year in the growing season seems to have a positively impact on the growth. Against expectations, the results recorded showed no strong correlation with altitude. Only the radial growth of the plot located at $1050 \mathrm{~m}$ a.s.l was positively and significantly influenced by the temperature at the beginning of vegetation season (i.e. May, Fig. 7).

Vavrčik et al. (2013), found in a study carried out in Brno (Czech Republic) at an altitude of $630 \mathrm{~m}$ a.s.l, that the cambium activity of beech began in May, with the maximum cambial activity being recorded in the second half of June. The complete formation of the annual tree ring has been recorded at the beginning of September (i.e. all wood cells had been formed by the cambium by mid-August and the fiber lignifications process had finished during the first half of September). The phenology 
632

of the annual ring formation varies from year to year, but shows a direct correlation with the environmental factors - temperature and precipitations. The temperature seems to be the determining factor in the ending of cambium activity (Vavrčik et al., 2013).

The results published in this study align themselves with the results recorded in previous studies, which showed a negative correlation between the temperature of the growing season and the radial growth; and a positive correlation between rainfallespecially rainfall in the growing season - and growth (Jump et al., 2007; Leca, 2014; Piovesan et al., 2005; Tegel et al., 2014). The water available in the months of May-June is essential for the values of radial growth in the current year and for the survival of beech in the long-term (Czúcz et al., 2011; Di Filippo et al., 2007; Dittmar et al., 2003; Lebourgeois et al., 2005).

In the years with the low values of the aridity index (1985, $1986,2000,2003)$ the tree rings are narrow. In the years in which the aridity index was in the optimal interval for beech (1959, $1970,2009,2014)$ were recorded higher values of the radial growth. For high values of De Martonne's index (50-54) which mark the upper limit in terms of altitude for beech - active growths have been recorded in the following years: 1970, 2005 and 2010. These results suggest that the amount of rainfall which is directly proportional with altitude - is crucial to the development of beech trees.

\section{Conclusions}

The analysis of the phenotypic traits, of tree growth dynamic and of natural regeneration along different environmental conditions shows that the investigated forest genetic resources have not been vulnerable to the climatic factors recorded for the last period. However, the negative correlation between air temperature and tree growth gives some predictions regarding a possible vertical displacement (from lower altitudes to higher altitudes) of the lower limit of beech distribution in the future.

Overall, the high values of the radial growth have been recorded for the rainy years. Similarly, high values for radial growth have been recorded in the situations where the aridity index had been recorded to be in the optimal range for beech. The primary limiting factor for beech forests located at the low altitudes is the temperature recorded in the growing season, also associated with a reduction in rainfall.

\section{Acknowledgements}

This paper was financed by the Romanian National Authority from Scientific Research and Innovation, in the frame of ANCSI Programme contracted with National Institute for Research and Development in Forestry "Marin Drăcea" (Project PN09460216). We wish to thank to our devoted colleagues: Dan Pepelea, Lucian Toiu, Tibor Şerban and Gabriela Lupu for their help in the field measurements. The authors express their gratitude to anonymous reviewers for their important contribution in the manuscript improvement.

\section{References}

Badea O (2008). Manual privind metodologia de supraveghere pe termen lung a stării ecosistemelor forestiere aflate sub acțiunea poluării atmosferice şi modificărilor climatice (Manual on the methodology for long term monitoring of forest ecosystems status under air pollution and climate change influences). Ed. Silvică, Bucharest.

Badea O, Neagu S, Bytnerowicz A, Silaghi D, Barbu I, Iacoban C, ... HuberV (2011). Long-term monitoring of air pollution effects on selected forest ecosystems in the Bucegi-Piatra Craiului and Retezat Mountains, southern Carpathians (Romania).iForest 4:49-60.

Bolte A, Czajkowski T, Kompa T (2007). The north-eastern distribution range of European beech-A review. Forestry 80:413-429.

Bouriaud O, Breda N, Le Moguedec G, Nepveu G (2004). Modelling variability of wood density in beech as affected by ring age, radial growth and climate. Trees-Structure and Function 18:264-276.

Brewer P,MurphyD,JansmaE(2011). TRiCYCLE: a universal conversion tool for digital tree-ring data. Tree-Ring Research 67(2):135-144.

Busuioc A, Caian M, Cheval S, Bojariu R(2010). Variabilitatea şi schimbarea climei (Variability and climatechange). Ed. Pro Universitaria, Bucharest.

Ceda catalogue (2014). The CRUTEM4 land-surface air temperature data set. Retrieved 15June 2015 from: http://catalogue.ceda.ac.uk

Cook ER, Kairiukstis LA (1990). Methods of Dendrochronology. Applications in the Environmental Sciences. Dordrecht, Kluwer Academic Publishers.

Cook ER, Krusic PJ (2006). ARSTAN4.1b_XP. From: http://www.ldeo.columbia.edu

CRU Dataset (2015). Climatic Research Unit, University of East, England. Retrieved 11 June2015 from: www.cru.uea.ac.uk.

Cybis Elektronik \& Data AB (2015). Cybis Dendrochronology and History. Cybis electronic and data, Saltsjöbaden, Sweden. From: www.cybis.se.

Czúcz B, Galhidy L, Matyas C (2011). Present and forecasted xeric climatic limits of beech and sessile oak distribution at low altitudes in Central Europe. Annals of Forest Science 68(1):99-108.

Di Filippo A, Biondi F, Cufar K, De Luis M, Grabner M, Maugeri M, ... Piovesan G (2007). Bioclimatology of beech (Fagus sylvatica L.) in the Eastern Alps: spatial and altitudinal climatic signals identified through a tree-ring network. Journal of Biogeography 34:1873-1892.

Dittmar C, Zech W, Elling W (2003). Growth variations of Common beech (Fagus sylvatica L.) under different climatic and environmental conditions in Europe: A dendroecological study. Forest Ecology and Management 173:63-78.

ECA\&D (2015). European Climate Assessment \& Dataset (ECA\&D). Retrieved 10June 2015 from: http://www.ecad.eu.

Ellenberg H (1988). Vegetation Ecology of Central Europe. Fourth ed. Cambridge University Press, Cambridge.

Fotelli MN, Nahm M, Radoglou K, Rennenberg H, Halyvopoulos G, Matzarakis A (2009). Seasonal and interannual ecophysiological responses of beech (Fagus sylvatica) at its south-eastern distribution limit in Europe. Forest Ecology and Management 257:1157-1164.

Führer E, Horváth L, Jagodics A, Machon A,Szabados I (2011). Application of a new aridity index in Hungarian forestry practice. Idöjárás 115:205216.

Giurgiu V, Decei I, Drăghiciu D (2004). Metode și tabele dendrometrice (Dendrometrical methods and tables).Ed. Ceres, Bucharest.

Granier A, Reichstein M, Bréda N, Janssens IA, Falge E, Ciais P, ... Wang Q (2007). Evidence for soil water control on carbon and water dynamics in 
European forests during the extremely dry year: 2003. Agricultural and Forest Meteorology 143:123-145.

Geßler A, Keitel C, Kreuzwieser J, Matyssek R, Seiler W, Rennenberg H (2007). Potential risks for European beech (Fagus sylvatica L.) in a changing climate. Trees 21:1-11.

Holmes R (1983). Computer-assisted quality control in tree-ring dating and measurement. Tree-ringBulletin 43:69-78.

Hulme M, Osborn TJ, Johns TC (1998). Precipitation sensitivity to global warming: Comparison of observations with HadCM2 simulations. Geophysical Research Letters 25:3379-3382.

Jump A, Hunt J, Peñuelas J (2007). Climate relationships of growth and establishment across the altitudinal range of Fagus sylvatica in the Montseny Mountains, northeast Spain. Ecoscience 14:507-518.

Klein Tank AMG, Wijngaard JB, Können GP, Böhm R, Demarée G, Gocheva A, ... Petrovic P (2002). Daily dataset of 20th-century surface air temperature and precipitation series for the European Climate Assessment. International Journal of Climatology 22:1441-1453.

Kramer K, Degen B, Buschbom J, Hickler T, Thuiller W, Sykes MT, de Winter W (2010). Modelling exploration of the future of European beech (Fagus sylvatica L.) under climate change - range, abundance, genetic diversity and adaptive response. Forest Ecology and Management 259:2213-2222.

Lebourgeois F, Bréda N, Ulrich E, Granier A (2005). Climate-tree growth relationships of European beech (Fagus sylvatica L.) in the French Permanent PlotNetwork(RENECOFOR). Trees 19:385-401.

Leca Ş (2014). Creșterea arborilor și arboretelor în sistemul de monitorizare forestieră intensivă (Trees and stands growth in intensive forest monitoring system). PhD Thesis, Transilvania Univ Braşov.

Michelot A, Simard S, Rathgeber C, Dufrêne E, Damesin C (2012). Comparing the intra-annual wood formation of three European species (Fagus sylvatica, Quercus petraea and Pinus sylvestris) as related to leaf phenology and non-structural carbohydrate dynamics. Tree Physiology 32:1033-1045.

Nahm M, Radoglou K, Rennenberg H, Chalyvopoulos G, Fotelli MN (2006). Physiological performance of beech (Fagus sylvatica L.) at its south-eastern distribution limit in Europe: seasonal changes in nitrogen, carbon and water balance. Plant Biology 8:52-63.

Oladi R, Pourtahmasi R, Eckstein D, Brauning A (2011). Seasonal dynamics of wood formation on Oriental beech (Fagus orientalis Lipsky) along an altitudinal gradient in the Hyrcanian forest, Iran. Trees 25:425-433.

Osborn TJ, Jones PD (2014). The CRUTEM4 land-surface air temperature data set: construction, previous versions and dissemination via Google Earth. Earth System Science Data 6:61-68.
Piovesan G, Di Filippo A, Alessandrini A, Biondi F, Schirone B (2005). Structure, dynamics and dendroecology of an old-growth Fagus forest in the Apennines. Journal of Vegetation Science 16:13-28.

Popa I (2004). Fundamente Metodologice și aplicații de dendrocronologie (Methodological fundamentals and applications of dendrochronology). Ed. Tehnică Silvică, Câmpulung Moldovenesc.

Rasztovits E (2011). Modelling the future distribution of beech at lowelevation xeric limits - comparison of empirical and stochastic models. $\mathrm{PhDD}$ issertation, Sopron.

Rozas V, Camarero JJ, Sanguesa-Barreda G, Sounto M, Garcia-Gonzalez I (2015). Summer drought and ENSO-related cloudiness distinctly drive Fagus sylvatica growth near the species rear-edge in northern Spain. Agricultural and Forest Meteorology 201:153-164.

Sandu I (2013). Climatic changes in Romania and the effects on water resources in agriculture. In: Proceedings of the International Symposium: Security of food and water resources: between European perspective and Romanian realities. Bucharest, $27 \mathrm{p}$.

Satmari A (2010). Lucrări practice de biogeografie (Practical applications of biogeography).Availableon: http://www.academia.edu/9909429/05_indici_ecometrici

Scharnweber T, Manthey M, Criegee C, Bauwe A, Schröder C, Wilmking $M$ (2011). Drought matters - Declining precipitation influences growth of Fagus sylvatica L. and Quercus robur L. in north-eastern Germany. Forest Ecology and Management 262:947-961.

Silva DE, Rezende Mazzella P, Legay M, Corcket E, Dupouey JL (2012). Does natural regeneration determine the limit of European beech distribution under climatic stress? Forest Ecology and Management 266:263-272.

Stojanović D, Kržič A, Matović B, OrlovićS, Duputie A, Djurdjević V, Galić Z, Stojnić S (2013). Prediction of the European beech (Fagus sylvatica L.) xeric limit using a regional climate model: An example from southeast Europe. Agricultural and Forest Meteorology 176:94103.

Şofletea N, Curtu L (2007). Dendrology. Ed. Transilvania University, Braşov.

Tegel W, Seim A, Hakelberg D, Hoffmann S, Panev M, Westphal T, Büntgen U (2014). A recent growth increase of European beech (Fagus sylvatica L.) at its Mediterranean distribution limit contradicts drought stress. European Journal of Forest Research 133:61-71.

Vavrčik H, Gryc V, Menšik L, Baar J (2012). Xylem formation in Fagus sylvatica during one growingseason. Dendrobiology 69:69-75. 